\title{
Review and clinical perspectives for the use of infliximab in ulcerative colitis
}

\author{
Remo Panaccione $M D^{1}$, Richard N Fedorak $M D^{2}$, Guy Aumais $M D^{3}$, Edmond-Jean Bernard $M D^{3}$, \\ Charles $\mathrm{N}$ Bernstein $\mathrm{MD}^{4}$, Alain Bitton $\mathrm{MD}^{5}$, Ken Croitoru $\mathrm{MDCM}^{6}$, Levinus A Dieleman MD PhD², \\ Robert Enns $M D^{7}$, Brian G Feagan $M D^{8}$, Denis Franchimont $\mathrm{MD}^{5}$, Gordon $\mathrm{R}$ Greenberg $M D^{9}$, \\ Anne-Marie Griffiths $M D^{9}$, John K Marshall $M D^{6}$, Pierre Pare $M D^{10}$, Sunil Patel $M D^{11}$, Robert Penner $M D^{2}$, \\ Craig Render $M D^{2}$, Ernest Seidman $M D^{5}$, A Hillary Steinhart $M D^{9}$
}

\begin{abstract}
R Panaccione, RN Fedorak, G Aumais, et al. Review and clinical perspectives for the use of infliximab in ulcerative colitis. Can J Gastroenterol 2008;22(3):261-272.

Infliximab is a chimeric, monoclonal anti-tumour necrosis factoralpha antibody. It has been previously demonstrated to be an effective treatment for patients with Crohn's disease who do not achieve the desired response with conventional treatments. Although the etiology of ulcerative colitis (UC) differs from that of Crohn's disease, randomized controlled trials have demonstrated that infliximab is also beneficial for the treatment of moderate to severe UC in patients who are either intolerant of or refractory to immunosuppressant agents or steroids, or those who are steroid-dependent. A review of the literature is followed by practical recommendations regarding infliximab that address the needs of clinicians and UC patients. Where there is a lack of evidence-based information, the expert panel provides its combined opinion derived from the members' clinical experiences.
\end{abstract}

\section{Une analyse et une perspective clinique pour l'utilisation de l'infliximab contre la colite ulcéreuse}

L'infliximab est un anticorps monoclonal chimérique de la tumeur de la nécrose antitumorale alpha. Il a déjà été démontré qu'il s'agit d'un traitement efficace pour les patients atteints de la maladie de Crohn qui ne répondent pas de la manière souhaitée aux traitements classiques. Létiologie de la colite ulcéreuse (CU) diffère de celle de la maladie de Crohn, mais des essais aléatoires et contrôlés ont démontré que l'infliximab est également bénéfique dans le traitement de la $\mathrm{CU}$ modérée à grave chez des patients intolérants ou réfractaires aux immunosuppresseurs ou aux stéroïdes ou stéroïdodépendants. Une analyse bibliographique est suivie de recommandations pratiques au sujet de l'infliximab qui répondent aux besoins des cliniciens et des patients atteints de CU. Lorsqu'on ne possède pas d'information probante, le comité d'experts fournit son opinion collective dérivée de l'expérience clinique des membres.

Key Words: Drug administration schedule; Immunomodulatory agents; Inflammatory bowel disease; Infliximab; Monoclonal antibodies; Ulcerative colitis

$\mathrm{T}$ he use of biological agents in the treatment of ulcerative colitis (UC) has recently been the subject of large-scale randomized controlled trials, and level 1 evidence of their efficacy has been provided by these trials. The accompanying paradigm shift in the management of UC is the impetus for the present review of the recent clinical studies on the use of infliximab in the treatment of UC. In the present paper, we place the specific findings of these studies in the context of clinical practice.

The present document represents the decisions reached during a meeting in Toronto, Ontario of invited expert gastroenterologists, all of whom have had extensive clinical experience with infliximab therapy for UC. Meeting and travel expenses were covered by a grant from the University of Alberta's Gastrointestinal and Liver Disease Research Group (Edmonton, Alberta) fund, which received an undirected educational grant from Schering Plough Canada Inc, the manufacturers of infliximab. Expenditures from this fund strictly followed University of Alberta policies and procedures. During the preparation of the manuscript, the authors' written comments were exchanged and compiled centrally. Each author has contributed to, reviewed and agreed on the content of the final document.

\section{INFLIXIMAB IN UC - REVIEW OF THE AVAILABLE EVIDENCE}

The present review of the available body of evidence provides an evidence-based approach to the use of the anti-tumour necrosis factor-alpha monoclonal antibody, infliximab, for the treatment of patients with UC. Gaps in this knowledge are also identified. For the physician's reference, Tables 1 and 2 provide descriptions of UC activity indexes that are commonly used both clinically and in key studies on UC.

For the present review, systematic literature searches were conducted using the following databases: PubMed, EMBASE, Cochrane Library and BIOSIS Previews. The following

${ }^{1}$ University of Calgary, Calgary; ${ }^{2}$ University of Alberta, Edmonton, Alberta; ${ }^{3}$ University of Montreal, Montreal, Quebec; ${ }^{4}$ University of Manitoba, Winnipeg, Manitoba; ${ }^{5}$ McGill University, Montreal, Quebec; ${ }^{6}$ McMaster University, Hamilton, Ontario; ${ }^{7}$ University of British Columbia, Vancouver, British Columbia; ${ }^{8}$ University of Western Ontario, London; ${ }^{9}$ University of Toronto, Toronto, Ontario; ${ }^{10}$ Laval University, Quebec City, Quebec; ${ }^{11}$ Dalhousie University, Halifax, Nova Scotia

Correspondence: Dr Richard Fedorak, University of Alberta, Division of Gastroenterology, Zeidler Ledcor Centre, Edmonton, Alberta T6G 2 X8. Telephone 780-492-6941,fax 780-492-8121,e-mail richard.fedorak@ualberta.ca

Received for publication September 19, 2007. Accepted September 19, 2007 
TABLE 1

Comparison of commonly used ulcerative colitis disease activity indexes

\begin{tabular}{|c|c|c|c|}
\hline \multirow[b]{2}{*}{ Clinical index } & \multicolumn{3}{|c|}{ Activity level } \\
\hline & Mild & Moderate & Severe \\
\hline $\begin{array}{l}\text { American College of } \\
\text { Gastroenterology (80) }\end{array}$ & $\begin{array}{l}<4 \text { stools/day } \pm \text { blood, normal ESR } \\
\text { and no sign of toxicity }\end{array}$ & $\begin{array}{l}\geq 4 \text { stools/day } \pm \text { blood and minimal } \\
\text { signs of toxicity }\end{array}$ & $\begin{array}{l}>6 \text { stools/day } \pm \text { blood, evidence of toxicity } \\
\quad \text { (fever, tachycardia, anemia or elevated ESR) }\end{array}$ \\
\hline Truelove and Witts (81) & $\begin{array}{l}<5 \text { bowel movements/day, small } \\
\text { amounts of blood in the stool, } \\
\text { no fever, no tachycardia, mild anemia } \\
(>75 \%, \text { approximately } 100 \mathrm{~g} / \mathrm{L}) \\
\text { and ESR }<30\end{array}$ & $\begin{array}{l}\text { Intermediate condition between mild } \\
\text { and severe }\end{array}$ & $\begin{array}{l}\geq 6 \text { bowel movements/day, large amounts of } \\
\text { blood in the stool, fever }\left(>37.5^{\circ} \mathrm{C}\right) \text {, pulse } \\
\text { (>90 beats/min), anemia (hemoglobin }>75 \% \\
\text { of baseline) and ESR }>30\end{array}$ \\
\hline Mayo score (82) & Score 3 to 5 & Score 6 to 9 & Score 10 to 12 \\
\hline $\begin{array}{l}\leq 2 \text { indicates clinical remission } \\
\text { if sustained for three days }\end{array}$ & $\begin{array}{l}1 \text { to } 2 \text { more stools/day than normal } \\
\text { Some blood in }<50 \% \text { of stools }\end{array}$ & $\begin{array}{l}3 \text { to } 4 \text { more stools/day than normal } \\
\text { Some blood in stools most of the time }\end{array}$ & $\begin{array}{l}\geq 5 \text { more stools/day than normal } \\
\text { Rectal bleeding, passing blood-only stools }\end{array}$ \\
\hline $\begin{array}{l}\text { Each of the four subcategories } \\
\text { (stools/day, bleeding, } \\
\text { endoscopy and physician's } \\
\text { global assessment) are } \\
\text { rated } 0 \text { to } 3 \text { in increasing } \\
\text { severity. The sum is the final } \\
\text { score ranging from } 0 \text { to } 12 \text {. }\end{array}$ & $\begin{array}{l}\text { Minimal rectal bleeding } \\
\text { Endoscopy shows erythema, mild } \\
\text { friability and/or decreased vascular } \\
\text { pattern } \\
\text { Physician's global assessment is mild } \\
\text { activity of disease }\end{array}$ & $\begin{array}{l}\text { Endoscopy shows marked erythema, } \\
\text { lack of vascular pattern, definite } \\
\text { friability and mucosal erosions } \\
\text { Physician's global assessment is } \\
\text { moderate disease activity }\end{array}$ & $\begin{array}{l}\text { Endoscopy shows spontaneous bleeding } \\
\text { and mucosal ulcerations } \\
\text { Physician's global assessment is severe } \\
\text { disease activity }\end{array}$ \\
\hline C-reactive protein (83) & $\geq 0 \mathrm{mg} / \mathrm{L}$ & $\geq 3 \mathrm{mg} / \mathrm{L}$ & $\geq 12 \mathrm{mg} / \mathrm{L}$ \\
\hline
\end{tabular}

ESR Erythrocyte sedimentation rate determined using the Wintrobe method

TABLE 2

Oxford ulcerative colitis disease activity index (84)

\begin{tabular}{ll}
\hline Patient profile with moderate ulcerative colitis & Patient profile with severe ulcerative colitis \\
\hline Ambulatory & May or may not be ambulatory \\
Between four and five stools/day with intermittent bleeding & In excess of five bloody or blood-only stools/day \\
May have tachycardia, fever or anemia & Has tachycardia, fever and anemia (may require transfusion) \\
Slightly elevated C-reactive protein level (approximately 3 mg/L) & Elevated C-reactive protein level (approximately 12 mg/L) \\
Radiograph normal, with possible small dilation or air & Radiograph indicates air, edematous wall or thumbprinting (85) \\
May have abdominal tenderness (85) & Abdominal tenderness (85) \\
General clinical condition: moderately ill and weak & General clinical condition: very ill and distressed
\end{tabular}

Characterizations of moderate and severe ulcerative colitis patient profiles are based on the activity indexes presented in Table 1. The Oxford Rule indicates that if a patient does not have a clinical response after five days of intensive steroid therapy, the individual requires surgical intervention before her/his condition deteriorates irreversibly (86)

search strings were used: infliximab and colitis (as text words); infliximab and inflammatory bowel diseases (as MeSH terms); and, infliximab and (ulcerative colitis) (as both text words and/or MeSH terms). From this search set, articles were selected only if they met the inclusion criteria: randomized controlled trials (RCTs), written in English, in which infliximab was used in human subjects for the treatment of UC.

Six publications representing seven studies were determined to meet the inclusion criteria (Table 3) (1-6). Each trial was conducted in either a closed-label or open-label, double-blind experimental setting. None of the studies investigated the use of infliximab for the treatment of pediatric patients or pouchitis.

Induction of remission in patients with steroid-refractory ulcerative colitis (fulminant colitis)

Three trials were conducted with patients whose disease was refractory to steroid therapy $(2,4,6)$. In 2001, Sands et al (6) compared the effects of infliximab therapy with those of a placebo. The patients' disease states were classified as severe according to the modified Truelove and Witts method (7), with scores ranging from 11 to 19 . UC was considered refractory to intravenous corticosteroid therapy after a minimum of five days. Eleven subjects were randomly assigned to one of four treatment arms: placebo $(\mathrm{n}=3)$, or infliximab at $5 \mathrm{mg} / \mathrm{kg}$ $(\mathrm{n}=3), 10 \mathrm{mg} / \mathrm{kg}(\mathrm{n}=3)$ or $20 \mathrm{mg} / \mathrm{kg}(\mathrm{n}=2)$. Patients received a single infusion at day 0 and were assessed at weeks 2 and 12 . Desired experimental end points were a modified Truelove and Witts score of less than 10 in conjunction with a five-point decrease from the patient's baseline score. At week 2, no improvement in disease status were recorded for the placebo group in comparison with the treatment groups $(5 \mathrm{mg} / \mathrm{kg}$ : two patients with disease improvement, $10 \mathrm{mg} / \mathrm{kg}$ : one patient with disease improvement, and $20 \mathrm{mg} / \mathrm{kg}$ : one patient with disease improvement). At week 12, only two infliximab subjects (each in $20 \mathrm{mg} / \mathrm{kg}$ group) had experienced durable treatment successes. In the remaining nine patients, colectomies were performed on all three patients receiving placebo and on four of the eight patients receiving infliximab $(5 \mathrm{mg} / \mathrm{kg}$ or $10 \mathrm{mg} / \mathrm{kg})$. The differences in results between infliximab and placebo were not statistically significant (RR 4.0, 95\% CI 0.28 to 57.98) (8). 
TABLE 3

Randomized controlled trials examining the effect of infliximab in the induction and maintenance of remission in ulcerative colitis

\begin{tabular}{|c|c|c|c|c|c|}
\hline \multirow[b]{2}{*}{ Reference } & \multirow{2}{*}{$\begin{array}{l}\text { Design, } 1^{\circ} \\
\text { outcome } \\
\text { period }\end{array}$} & \multicolumn{3}{|c|}{ Group } & \multirow[b]{2}{*}{ Results } \\
\hline & & Infliximab regimen & Comparator & Concomitant therapy & \\
\hline \multicolumn{6}{|c|}{ Induction of remission } \\
\hline $\begin{array}{l}\text { Sands et al, } \\
2001(6)\end{array}$ & $\begin{array}{l}\mathrm{DB} \\
2 \text { weeks }\end{array}$ & $\begin{array}{l}5 \mathrm{mg} / \mathrm{kg} \text { daily }(\mathrm{n}=3) \\
10 \mathrm{mg} / \mathrm{kg} \text { daily }(\mathrm{n}=3) \\
20 \mathrm{mg} / \mathrm{kg} \text { daily }(\mathrm{n}=2)\end{array}$ & Placebo $(n=3)$ & $\begin{array}{l}\text { Sulfasalazine, mesalazine, } \\
\text { antibiotics, azathioprine, } \\
\text { 6-MP and antidiarrheal drugs }\end{array}$ & $\begin{array}{l}\text { No significant difference in disease } \\
\text { improvement }\end{array}$ \\
\hline $\begin{array}{c}\text { Probert et al } \\
2003(4)\end{array}$ & $\begin{array}{l}\text { I,DB, } \\
6 \text { weeks }\end{array}$ & $\begin{array}{l}5 \mathrm{mg} / \mathrm{kg} \text { daily at weeks } 0 \\
\text { and } 2(\mathrm{n}=23)\end{array}$ & Placebo at weeks 0 and $2(n=20)$ & $\begin{array}{l}\text { Acetaminophen, 5-ASA, } \\
\text { glucocorticoids, } \\
\text { azathioprine and 6-MP }\end{array}$ & $\begin{array}{l}\text { No significant difference in disease } \\
\text { improvement but there was a trend } \\
\text { toward favouring infliximab treatment }\end{array}$ \\
\hline $\begin{array}{l}\text { Armuzzi } \\
\text { et al, } \\
2004 \text { (1) }\end{array}$ & $\begin{array}{l}\text { OL, } \\
2 \text { weeks }\end{array}$ & $\begin{array}{l}5 \mathrm{mg} / \mathrm{kg} \text { daily at weeks } 0 \\
2 \text { and } 6(n=10)\end{array}$ & $\begin{array}{l}\text { Intravenous methylprednisolone } \\
0.7 \mathrm{mg} / \mathrm{kg} \text { to } 1 \mathrm{mg} / \mathrm{kg} \text { daily for } \\
\text { one week, then tapered }(\mathrm{n}=10)\end{array}$ & Prednisolone & $\begin{array}{l}\text { No significant difference between } \\
\text { treatment groups }\end{array}$ \\
\hline $\begin{array}{l}\text { Ochsenkuhn } \\
\text { et al, } \\
2004 \text { (3) }\end{array}$ & $\begin{array}{l}\text { DB, } \\
13 \text { weeks }\end{array}$ & $\begin{array}{l}5 \mathrm{mg} / \mathrm{kg} \text { daily at weeks } 0 \\
2 \text { and } 6(\mathrm{n}=6)\end{array}$ & $\begin{array}{l}\text { Oral prednisolone } 1.5 \mathrm{mg} / \mathrm{kg} \\
\text { daily for two weeks, } \\
\text { then tapered }(\mathrm{n}=7)\end{array}$ & $\begin{array}{l}\text { Mesalazine, sulfasalazine, } \\
\text { antibiotics and antidiarrheal } \\
\text { drugs }\end{array}$ & $\begin{array}{l}\text { No significant difference in disease } \\
\text { improvement }\end{array}$ \\
\hline $\begin{array}{l}\text { Jarnerot } \\
\text { et al, } \\
2005(2)\end{array}$ & $\begin{array}{l}\mathrm{DB} \\
3 \text { months }\end{array}$ & $\begin{array}{l}4 \mathrm{mg} / \mathrm{kg} \text { to } 5 \mathrm{mg} / \mathrm{kg} \\
\text { daily }(\mathrm{n}=24)\end{array}$ & Placebo $(n=21)$ & $\begin{array}{l}\text { Optional: Oral prednisolone } \\
40 \mathrm{mg} \text { daily with } 5 \mathrm{mg} \\
\text { reduction/week, mesalamine } \\
\text { and azathioprine } 1.5 \mathrm{mg} / \mathrm{kg} \\
\text { to } 2 \mathrm{mg} / \mathrm{kg} \\
\text { Required: Trimethoprim } 160 \mathrm{mg} \\
\text { and sulfamethoxazole } 800 \mathrm{mg} \\
\text { daily for } 8 \text { weeks }\end{array}$ & $\begin{array}{l}\text { Infliximab significantly reduced the } \\
\text { colectomy rate (RR } 0.44,95 \% \mathrm{Cl} 0.22 \\
\text { to } 0.87 \text { ). There were no other } \\
\text { significant differences between the } \\
\text { two study groups } \\
\text { g }\end{array}$ \\
\hline $\begin{array}{l}\text { Rutgeerts } \\
\text { et al, } \\
2005 \text { (5), } \\
\text { (ACT 1) }\end{array}$ & $\begin{array}{l}\mathrm{DB} \\
8 \text { weeks }\end{array}$ & $\begin{array}{l}5 \mathrm{mg} / \mathrm{kg} \text { daily at weeks } 0 \text {, } \\
2 \text { and } 6 \text {, then every } \\
\text { eight weeks to } \\
\text { week } 46(\mathrm{n}=121) \\
10 \mathrm{mg} / \mathrm{kg} \text { daily at weeks } 0 \text {, } \\
2 \text { and } 6 \text {, then every } \\
\text { eight weeks to } \\
\text { week } 46(\mathrm{n}=122)\end{array}$ & $\begin{array}{l}\text { Placebo at weeks } 0,2 \text { and } 6, \\
\text { then every eight weeks } \\
\text { to week } 46(n=121)\end{array}$ & $\begin{array}{l}\text { Corticosteroids, 5-ASA, } \\
\text { azathioprine and 6-MP }\end{array}$ & $\begin{array}{l}\text { Clinical response in } 69.4 \% \text { and } 61.5 \% \\
\text { of patients receiving infliximab at } \\
5 \mathrm{mg} / \mathrm{kg} \text { or } 10 \mathrm{mg} / \mathrm{kg} \text { daily, } \\
\text { respectively versus } 37.2 \% \text { receiving } \\
\text { placebo ( } \mathrm{P}<0.001 \text { for both } \\
\text { comparisons) }\end{array}$ \\
\hline $\begin{array}{l}\text { Rutgeerts } \\
\text { et al, } \\
2005 \text { (5), } \\
\text { (ACT 2) }\end{array}$ & $\begin{array}{l}\text { DB, } \\
8 \text { weeks }\end{array}$ & $\begin{array}{l}5 \mathrm{mg} / \mathrm{kg} \text { daily at weeks } 0, \\
2 \text { and } 6 \text {, then every } \\
\text { eight weeks to } \\
\text { week } 22(\mathrm{n}=121) \\
10 \mathrm{mg} / \mathrm{kg} \text { daily at weeks } 0, \\
2 \text { and } 6 \text {, then every } \\
\text { eight weeks to } \\
\text { week } 22(\mathrm{n}=120)\end{array}$ & $\begin{array}{l}\text { Placebo at weeks } 0,2 \text { and } 6 \text {, } \\
\text { then every eight weeks } \\
\text { to week } 22(n=123)\end{array}$ & $\begin{array}{l}\text { Corticosteroids, 5-ASA, } \\
\text { azathioprine and 6-MP }\end{array}$ & $\begin{array}{l}\text { Clinical response in } 64.5 \% \text { and } 69.2 \% \\
\text { of patients receiving infliximab at } \\
5 \mathrm{mg} / \mathrm{kg} \text { or } 10 \mathrm{mg} / \mathrm{kg} \text { daily, } \\
\text { respectively versus } 29.3 \% \text { receiving } \\
\text { placebo ( } P<0.001 \text { for both } \\
\text { comparisons) }\end{array}$ \\
\hline \multicolumn{6}{|c|}{ Maintenance of remission } \\
\hline $\begin{array}{l}\text { Rutgeerts } \\
\text { et al, } \\
2005 \text { (5), } \\
\text { (ACT 1) }\end{array}$ & $\begin{array}{l}\mathrm{DB} \\
54 \text { weeks }\end{array}$ & $\begin{array}{l}5 \mathrm{mg} / \mathrm{kg} \text { daily at weeks } 0, \\
2 \text { and } 6 \text {,then every } \\
\text { eight weeks to } \\
\text { week } 46(\mathrm{n}=121) \\
10 \mathrm{mg} / \mathrm{kg} \text { daily at weeks } 0 \text {, } \\
2 \text { and } 6 \text {, then every } \\
\text { eight weeks to } \\
\text { week } 46(n=122)\end{array}$ & $\begin{array}{l}\text { Placebo at weeks } 0,2 \text { and } 6 \text {, } \\
\text { then every eight weeks } \\
\text { to week } 46(n=121)\end{array}$ & $\begin{array}{l}\text { Corticosteroids, 5-ASA, } \\
\text { azathioprine and 6-MP }\end{array}$ & $\begin{array}{l}\text { Clinical remission in } 34.7 \% \text { and } 34.4 \% \\
\text { of patients receiving infliximab at } \\
5 \mathrm{mg} / \mathrm{kg} \text { or } 10 \mathrm{mg} / \mathrm{kg} \text { daily, } \\
\text { respectively versus } 16.5 \% \text { receiving } \\
\text { placebo ( } \mathrm{P}=0.001 \text { for both } \\
\text { comparisons) }\end{array}$ \\
\hline $\begin{array}{l}\text { Rutgeerts } \\
\text { et al, } \\
2005 \text { (5), } \\
\text { (ACT 2) }\end{array}$ & $\begin{array}{l}\mathrm{DB} \\
30 \text { weeks }\end{array}$ & $\begin{array}{l}5 \mathrm{mg} / \mathrm{kg} \text { daily at weeks } 0, \\
2 \text { and } 6 \text {, then every } \\
\text { eight weeks to } \\
\text { week } 22(\mathrm{n}=121) \\
10 \mathrm{mg} / \mathrm{kg} \text { daily at weeks } 0, \\
2 \text { and } 6 \text {, then every } \\
\text { eight weeks to } \\
\text { week } 22(\mathrm{n}=120)\end{array}$ & $\begin{array}{l}\text { Placebo at week } 0,2 \text { and } 6, \\
\text { then every eight weeks } \\
\text { to week } 22(n=123)\end{array}$ & $\begin{array}{l}\text { Corticosteroids, 5-ASA, } \\
\text { azathioprine and 6-MP }\end{array}$ & $\begin{array}{l}\text { Clinical remission in } 25.6 \% \text { and } 35.8 \% \\
\text { of patients receiving infliximab at } \\
5 \mathrm{mg} / \mathrm{kg} \text { or } 10 \mathrm{mg} / \mathrm{kg} \text { daily, } \\
\text { respectively versus } 10.6 \% \text { receiving } \\
\text { placebo ( } \mathrm{P}=0.003 \text { and } \mathrm{P}<0.001, \\
\text { respectively) }\end{array}$ \\
\hline
\end{tabular}


Although the above study did not show a statistical significance for the antibody treatment, it was the first to suggest that a response to a single infusion of infliximab could occur in some cases of severe UC. However, the study's outcome was overshadowed by its small patient population $(n=11)$, which was attributed to difficult patient enrolment. The authors did not comment on whether attempts were made to wean 'infliximab responders' off of concomitant corticosteroid therapy.

In 2003, Probert et al (4) reported on an RCT that enrolled 43 subjects with moderate-to-severe UC (UC symptom score of more than 6) whose disease was refractory to seven days of prednisolone therapy $(30 \mathrm{mg} /$ day $)$. Patients received an infusion of either placebo $(\mathrm{n}=20)$ or $5 \mathrm{mg} / \mathrm{kg}$ of infliximab $(\mathrm{n}=23)$ at days 0 and 14 . The primary experimental end point was an UC symptom score of 2 or less at week 6 . In the infliximab arm, $39 \%$ of cases (nine of 23 ) met this end point, relative to $30 \%$ (six of 20) in the placebo arm. All infliximab responders had their corticosteroid therapy tapered during weeks 2 to 6 . Only one colectomy was performed; it took place in the placebo group. In the infliximab group, 11 subjects with nonresponding disease received a third infliximab infusion of $10 \mathrm{mg} / \mathrm{kg}$ at week 6 as a rescue therapy. Of this number, three cases met the success criteria four weeks after the last infusion.

In spite of the fact that Probert et al (4) used a two-step infusion regimen and had a larger patient population that had less severe disease activity than that seen in Sands et al (6), the clinical outcomes were similar in these first two studies. Indeed, Probert et al found no statistically significant difference between the two treatment arms in terms of clinical remission or quality of life (measured using the Inflammatory Bowel Disease Questionnaire and the EuroQol scale). Differences in endoscopic remission rates did not achieve statistical significance either, with a RR of 0.87 and a $95 \%$ CI of 0.33 to $2.27(8)$.

More recently, in 2005, Jarnerot et al (2) published an RCT of patients $(n=45)$ with moderate and severe UC (Seo index score of 150 to 220 and more than 220, respectively). At day 0 , all subjects were started on intravenous betamethasone (4 mg two times per day). Patients were randomly assigned to receive either a single infusion of placebo $(n=21)$ or infliximab ( $4 \mathrm{mg} / \mathrm{kg}$ to $5 \mathrm{mg} / \mathrm{kg}$ ) ( $\mathrm{n}=24)$ depending on their response to the high-dose steroid therapy. Patients who had a fulminant colitis score of 8 or more on day 3 received infusions on day 4 . Patients with Seo index scores of more than 150 received infusions on days 6 to 8 . The primary experimental end points were colectomy or death 90 days after the infusion. Clinical remission was considered to have been attained if the Seo index was less than 150 points and endoscopies showed disease to be in remission at both 30 and 90 days. All responders underwent a standard corticosteroid tapering schedule. At 90 days, colectomies had been performed on seven of 24 infliximab patients and 14 of 21 placebo patients $(\mathrm{P}=0.017)$. There were no deaths in the study. Overall, neither clinical remission rates (six of 24 infliximab patients and two of 21 placebo patients) nor endoscopic remission rates (six of 15 patients and two of six placebo patients) of infliximab patients were statistically different from placebo patients at 90 days (RR 2.63, 95\% CI 0.59 to 11.64$)(8)$.

The key differences of the study by Jarnerot et al from the previous ones by Sands et al and Probert et al were the longer assessment periods of three and six months and a standard corticosteroid tapering schedule for responders. Additionally, Jarnerot et al used primary experimental end points that were clinically relevant (ie, colectomy and death). All three of the above studies were statistically underpowered due to their small patient populations.

\section{Induction of remission in steroid-dependent UC}

In 2004, Armuzzi et al (1) reported on an RCT that aimed to determine the effectiveness of infliximab for patients whose UC was steroid-dependent. Twenty patients with mild-tomoderate UC (disease activity index [DAI] score of more than 6) were randomly assigned to receive either infliximab $(n=10$; $5 \mathrm{mg} / \mathrm{kg}$ at zero, two and six weeks, followed by maintenance infusions every six weeks) or intravenous methylprednisolone ( $\mathrm{n}=10 ; 0.7 \mathrm{mg} / \mathrm{kg}$ to $1 \mathrm{mg} / \mathrm{kg}$ body weight daily for one week, followed by a tapering regimen). Clinical remission was defined as a DAI score of less than 3. At three and six months, both treatment groups achieved clinical remission.

This was the first RCT to implement a regimen of a tripleinfliximab infusion for induction followed by infusions to maintain remission (DAI score of less than 3). The study also demonstrated the benefit of infliximab therapy for responders, who were able to taper and then discontinue steroids during the maintenance phase (nine of 10 patients), as compared with the methylprednisolone group (eight of 10 patients), where responders required continued steroid therapy (mean \pm $\mathrm{SD}, 16.25 \pm 5.2 \mathrm{mg} /$ day at six months). However, this study was also statistically underpowered.

\section{Induction of remission in patients with UC that is neither steroid-refractory nor steroid-dependent}

In 2004, Ochsenkuhn et al (3) reported the results of their RCT involving 13 patients with moderate-to-severe UC that was neither steroid-dependent nor steroid-refractory. These patients' modified Truelove and Witts scores were more than 10 for a minimum of two weeks before the trial. Participants were randomly assigned to one of two treatment arms: infliximab (5 mg/kg at weeks 0,2 and 6) or prednisolone $(1.5 \mathrm{mg} / \mathrm{kg}$ daily for two weeks, then $1 \mathrm{mg} / \mathrm{kg}$ for one week followed by a weekly $5 \mathrm{mg}$ reduction). End points at weeks 3 and 13 were a modified Truelove and Witts score of less than 10 and a fivepoint decrease or more from the baseline score. At both end points, results from five of six and six of seven patients from the infliximab and prednisolone groups, respectively, showed therapeutic success. No statistical differences between the two treatment groups were observed with respect to treatment success and endoscopic remission rates.

This small study by Ochsenkuhn et al suggested that infliximab therapy (without concomitant steroid therapy) had similar efficacy to high-dose steroid treatment. This similarity raised the possibility of using infliximab to induce and maintain remission of less severe UC, as a steroid-sparing treatment.

In 2005, Rutgeerts et al (5) published two large-scale RCTs (Active Ulcerative Colitis Trial [ACT] 1 and ACT 2) that compared the efficacy of infliximab to that of a placebo for the induction of remission in cases of moderate-to-severe UC. The use of infliximab to maintain long-term remission was concurrently investigated. In both ACT 1 and ACT 2, study participants were ambulatory patients who had Mayo scores of between 6 and 12 in spite of concurrent treatment with mesalamine (ACT 2 only), corticosteroids, azathioprine or 6-mercaptopurine. At the point of random assignment, 30.8\% 
$(n=112)$ and $28.8 \%(n=105)$ of patients had steroid-refractory UC in ACT 1 and ACT 2, respectively. In ACT 1, 364 patients were randomly assigned to receive infusions of either infliximab, at $5 \mathrm{mg} / \mathrm{kg}(\mathrm{n}=121)$ or $10 \mathrm{mg} / \mathrm{kg}(\mathrm{n}=122)$, or placebo $(n=121)$ at weeks 0,2 and 6 , and every eight weeks thereafter to week 46. A clinical response was defined as a three-point decrease from the baseline score, along with a reduction in rectal bleeding. Clinical remission was considered to have been achieved when the Mayo score was 2 or less. The primary end point was at week 8 , and the secondary end points were at weeks 30 and 54. In ACT 2, 364 patients were randomly assigned to receive infusions of either infliximab, at $5 \mathrm{mg} / \mathrm{kg}(\mathrm{n}=121)$ or $10 \mathrm{mg} / \mathrm{kg}(\mathrm{n}=120)$ or placebo $(\mathrm{n}=123)$ at weeks 0,2 and 6 , and every eight weeks thereafter through week 22. The ACT 1 criteria for clinical response and clinical remission were used in ACT 2. The ACT 2 primary and secondary end points were at eight and 30 weeks.

The outcomes of both ACT 1 and ACT 2 were statistically in favour of infliximab. No difference in clinical response was found in the group of patients whose disease was steroidrefractory from the group of patients whose disease was not steroid refractory in the two trials. A Cochrane review and meta-analysis (8) of the combined results $(n=728)$ demonstrated that infliximab successfully induced clinical remission (RR 3.22, 95\% CI 2.18 to 4.76 ) in 160 of 484 patients (33.1\%), versus 25 of 244 patients (10.2\%) taking the placebo. Infliximab also successfully induced endoscopic remission (RR 1.88, 95\% CI 1.54 to 2.28; four patients needed to be treated to prevent one recurrence) at eight weeks in 294 of 484 patients $(60.7 \%)$, versus 79 of 244 patients (32.4\%) taking a placebo (8).

\section{Maintenance of remission in patients with UC that is neither steroid-refractory nor steroid-dependent}

The ACT 1 and ACT 2 trials (5) are the only studies to date to employ infliximab to maintain remission of UC. Maintenance infusions of either infliximab (5 mg/kg or $10 \mathrm{mg} / \mathrm{kg}$ ) or placebo were administered beginning at week 14 , and every eight weeks thereafter, through week 46 (ACT 1) or week 22 (ACT 2). By week 30 in ACT $1,33.9 \%$ and $36.9 \%$ of patients receiving infliximab (5 mg/kg and $10 \mathrm{mg} / \mathrm{kg}$, respectively) experienced a clearly maintained clinical remission $(\mathrm{P}=0.001$ and $\mathrm{P}<0.001$, respectively) versus only $15.7 \%$ of the patients in the placebo arm. The ACT 2 results were similar, in that $25.6 \%$ and $35.8 \%$ of the infliximab patients $(5 \mathrm{mg} / \mathrm{kg}$ and $10 \mathrm{mg} / \mathrm{kg}$, respectively) were in clinical remission at week $30(\mathrm{P}=0.003$ and $\mathrm{P}<0.001$, respectively) versus $10.6 \%$ of the placebo group. In ACT 1, at week 54 , there was still a significant difference between the infliximab and placebo treatment arms with respect to maintenance of clinical remission. In the $5 \mathrm{mg} / \mathrm{kg}$ infliximab study group, $34.7 \%$ of the patients were in clinical remission $(\mathrm{P}=0.001)$ versus $34.4 \%$ in the $10 \mathrm{mg} / \mathrm{kg}$ group. Only $16.5 \%$ of patients receiving the placebo had a maintained clinical remission at week $54(\mathrm{P}=0.001)$. No information was provided regarding the remission statuses of the subgroups whose disease was or was not refractory to steroids in either trial. While outcomes at 30 and 52 weeks continued to favour active therapy, further studies are needed to establish the therapeutic gain of long-term maintenance therapy beyond one year.

\section{Safety}

The common infliximab-attributable adverse effects reported in four of the RCTs $(2-4,6)$ were generally mild. They included pruritis, headache and upper respiratory or urinary tract infections. In the ACT 1 and ACT 2 studies (5), placebo and infliximab treatment groups had similar rates of adverse events and infusion reactions. However, one infliximabtreated patient in each of the ACT 1 and ACT 2 studies developed an opportunistic infection (tuberculosis and histoplasmosis, respectively) and died of complications. Delayed hypersensitivity reactions were reported for two patients treated with infliximab (one each in ACT 1 and ACT 2) and one patient receiving placebo (ACT 1) (5). No malignancies or lymphomas were reported in these RCTs, although the risk of neoplasia associated with infliximab and other biological agents is described.

\section{Concomitant immunomodulatory therapy}

Although many patients in these RCTs received concomitant treatment with azathioprine, mesalamine, antibiotics or methotrexate, these drugs' confounding influence on study end points was minimized through the initial randomization process. In the RCTs on steroid-refractory and steroiddependent disease, all subjects were treated with infliximab in conjunction with steroid therapy $(1,2,4,6)$. However, only the RCTs conducted by Ochsenkuhn et al (3) and Rutgeerts et al (5) were able to assess (and exclude) the possibility of a synergistic effect between infliximab and concomitant steroid therapy. Indeed, in the case of intermittent infliximab dosing, where anti-infliximab antibody rates are generally high, concomitant administration of immunomodulatory drugs (azathioprine, 6-mercaptopurine and methotrexate) has been shown to reduce the formation of antibodies, improve efficacy and reduce infusion reactions. The possibility of a similar beneficial effect to concomitant immunomodulatory therapy along with scheduled infliximab dosing is less clearly established and has recently been challenged $(9,10)$. The clinical approach to the immunogenicity of infliximab has been reviewed elsewhere $(11,12)$.

\section{Knowledge gaps and potential future areas of research} A considerable number of gaps exist in the clinical knowledge related to infliximab. Not all patients are responsive to infliximab therapy induction, and there is currently no phenotypic, genotypic, metabolic or serological profile that predicts a response to this therapy. In the case of severe UC, no RCT has yet compared the success of infliximab to that of intravenous cyclosporine, nor has any trial assessed the outcomes of their sequential use.

The clinician should be aware that the ACT 1 and ACT 2 trials examined a mixed group of patients, which included both those who were steroid-dependent and/or immunomodulator-dependent and those who were steroidresponsive and/or immunomodulator-responsive. Caution should be used when extrapolating these results to the treatment of steroid-dependent or steroid-resistant UC. Further studies are required to determine the results of concomitant immunosuppressant therapy and infliximab therapy. There also remains a considerable knowledge gap to do with the optimal remission maintenance regimen. Because no studies of infliximab have exceeded 54 weeks, the benefits of continued maintenance therapy, as well as its long-term safety, are unknown. The optimal use of infliximab, in terms of ondemand, episodic maintenance versus scheduled-maintenance therapy, is also unclear. 


\section{Summary}

In total, seven RCTs have assessed the effectiveness of infliximab therapy for varying degrees of mild-to-severe UC. The most convincing data for the efficacy of infliximab in UC comes from the large ACT 1 and ACT 2 trials, in which ambulatory patients whose disease was neither refractory to nor dependent on steroid therapy received three $5 \mathrm{mg} / \mathrm{kg}$ infusions at weeks 0,2 and 6 for induction purposes, followed by infusions every eight weeks for maintenance therapy.

\section{INFLIXIMAB IN UC - IMPLICATIONS FOR CLINICAL PRACTICE}

\section{Target population}

In the absence of a formal consensus process approved by the Canadian Association of Gastroenterology, these implications for adult and pediatric clinical practice should not be considered guidelines but instead, expert opinions based on evidence from observational, cohort and randomized studies.

\section{Clinical indications}

\section{Moderate-to-severe UC (nonfulminant colitis)}

Clinical practice considerations

Infliximab has received Notice of Compliance approval in Canada for its use in the induction and maintenance of remission for UC that is dependent, intolerant or refractory to one or a combination of the following therapies: steroids, azathioprine, 6-mercaptopurine and/or mesalamine (1,4,5,13-16).

\section{Commentary}

- In general, in the absence of contraindications, patients whose disease has failed to respond to oral (4 g) and/or topical mesalamine after two weeks should be given one therapeutic trial of corticosteroids. If the UC is steroid-dependent, immunosuppressive agents (eg, azathioprine at $2.5 \mathrm{mg} / \mathrm{kg}$ or 6 -mercaptopurine at $1.5 \mathrm{mg} / \mathrm{kg}$ ) should be used before considering infliximab treatment.

- The evidence for the use of immunosuppressive therapy with purine antimetabolites in the management of active $\mathrm{UC}$ is less robust than the evidence that supports their use to treat Crohn's disease.

- The strongest evidence comes from an RCT conducted by Ardizzone et al (17), in which steroid-dependent patients with active disease were treated with either mesalamine or azathioprine. More patients attained remission and were weaned off steroids with the azathioprine treatment than with the mesalamine treatment ( $53 \%$ versus $21 \%$ ) (OR 4.78, 95\% CI 1.57 to 14.5 ).

- Another RCT by Hawthorne et al (18) showed that withdrawal of azathioprine was associated with a higher relapse rate than was azathioprine when used to maintain remission for a randomly assigned population. However, this trial, although randomized, did not utilize a doubleblind design. Therefore, in making the decision to use immunosuppressive agents to treat UC, the clinician must bear in mind the current level of evidence and the potential risk of malignancies for patients on combination immunomodulatory and anti-tumour necrosis factor-alpha therapy (please see below).
- The use of concomitant immunosuppressive agents to abrogate the antibody response to infliximab has been recommended by experts if intermittent use of infliximab is planned. However, in the case of regular maintenance doses of infliximab, the use of concomitant immunosuppressive therapy is a controversial practice.

- No published evidence exists to support the use of methotrexate to induce or maintain remission of UC (19-21). However, in the case of azathioprine intolerance, some clinicians opt to use methotrexate to abrogate the antibody response to infliximab, especially if intermittent infliximab dosing is contemplated. For patients who cannot take azathioprine, results from trials and treatment of rheumatoid arthritis suggest that the administration of methotrexate may be a suitable alternative to help minimize an antibody response (21-23).

Evidence from observational studies indicates that pediatric patients should have the same infliximab treatment options that are available to adults $(13-16,24)$. However, greater concern exists regarding the lymphoma risk associated with combined azathioprine and infliximab therapy for young patients than for adults with Crohn's disease and UC. Recent reports have documented the occurrence of an otherwise exceedingly rare, and usually fatal, hepatosplenic T-cell lymphoma among pediatric patients receiving a thiopurine drug along with infliximab on a long-term basis $(25-27)$. These reports have led some experts to recommend against long-term immunosuppression therapy when infliximab is administered on a regular maintenance schedule.

\section{Severe UC (including fulminant colitis) \\ Clinical practice considerations}

For patients with severe UC who require hospitalization and who show either no response or a partial response to three to seven days of intravenous corticosteroids, limited evidence suggests that infliximab therapy may result in a clinical response and remission in some cases $(2,6)$.

\section{Commentary}

- Fulminant disease may respond less well than severe nonfulminant disease (2). Consultation with those who have expertise in the management of patients with these disease conditions is important, to ensure positive outcomes. Referral of patients to centres with surgical and medical expertise in the management of these patients can be important. A multidisciplinary approach involving both medical and surgical teams will maximize treatment efficacy and minimize the occurrence of adverse events.

- To date, no direct comparison of the effectiveness of infliximab versus cyclosporine for UC has been published $(28,29)$.

- Evidence from observational studies indicate that pediatric patients should be offered the same infliximab treatment options that are available to adults (30-35).

Initial dosing (induction of remission)

\section{Moderate-to-severe UC}

Clinical practice considerations

The recommended dosing regimen (based on the ACT trials) for induction of remission is three intravenous infusions of 
infliximab $(5 \mathrm{mg} / \mathrm{kg})$ at zero, two and six weeks. Other multiple dosing regimens for UC treatment (ie, zero and two weeks), including multiple versus single-dosing regimens, have not been compared in RCTs $(1,3,5,31,35,36)$.

\section{Severe UC}

Clinical practice considerations

The initial dose of infliximab is an intravenous infusion (5 mg/kg) at week 0 . Patients with severe UC should be assessed on a daily basis while in the hospital. For those patients whose disease responds to the therapy, subsequent infliximab infusions can be repeated at weeks 2 and 6 $(5 \mathrm{mg} / \mathrm{kg}$ ). In general, patients whose disease does not respond, or that continues to deteriorate in spite of receiving infliximab therapy, should be considered for surgery.

\section{Concomitant immunosuppressive therapy}

Clinical practice considerations

The rationale for combined immunosuppressive therapy is to minimize the formation of antibodies to infliximab and thereby enhance drug efficacy and reduce infusion reactions. Evidence extrapolated from Crohn's disease and rheumatoid arthritis trials suggests that concomitant immunomodulatory therapy with azathioprine or 6-mercaptopurine can be considered (37). The risk-benefit ratio for this approach is better if intermittent infliximab dosing is anticipated and is less robust if regularly scheduled infliximab dosing is planned.

\section{Commentary}

- The potential adverse event profiles of concomitant immunosuppressive therapy (see above) must be taken into consideration before this therapy is initiated.

- In general, immunosuppressant treatments should be started before infliximab therapy to minimize infusion reactions and antibody formation (38). The optimum dose and duration of immunosuppression is unknown; however, experts are using similar doses to those suggested for Crohn's disease.

- In the case of patients who cannot tolerate either azathioprine or 6-mercaptopurine, some experts have used methotrexate to prevent infusion reactions and antibody formation. However, there is no RTC evidence to suggest that methotrexate is effective for the management of UC.

\section{Maintenance dosing for both moderate-to-severe and severe UC patients \\ Clinical practice considerations}

No RCT has yet attempted to determine the optimal dosing of infliximab for maintaining remission in UC. The ACT 1 and ACT 2 trials used maintenance dosing of $5 \mathrm{mg} / \mathrm{kg}$ on a scheduled basis every eight weeks to maintain clinical remission following completion of an induction regimen for 30 and 52 weeks, respectively $(1,5,30,35)$. For patients who have lost the response, a reinduction regimen of infliximab may reestablish a response in some cases $(31,39-41)$. While outcomes at 30 and 52 weeks continued to favour active therapy, further studies are needed to establish the therapeutic gain of long-term maintenance therapy beyond one year.

\section{Commentary}

- Given the low toxicity of mesalamine, its proven maintenance efficacy in cases of mild UC, and the emerging evidence for the use of mesalamine as a chemotherapeutic agent for the prevention of colon cancer, the majority of experts support the discontinued use of mesalamine by patients who require long-term infliximab therapy. For patients receiving concurrent mesalamine and immunosuppressive agents, close monitoring of white blood cell counts is recommended, because a drug interaction may promote neutropenia (42).

- Corticosteroid therapy should be tapered and discontinued once a patient has responded to infliximab therapy. If a patient cannot be weaned off steroids after the introduction of infliximab, a re-evaluation of the continued use of infliximab for long-term disease management is necessary $(1,3-5,24,33,35,43-46)$.

- Intermittent (or 'on demand') infliximab dosing as a maintenance strategy in UC has not been studied. However, because of antibody formation, this approach has not been recommended for the treatment of other immune-mediated diseases (47).

- No studies are available concerning the benefits or risks of continuing infliximab maintenance therapy for longer than 12 months, although some experts have successfully used scheduled infliximab maintenance dosing for more than five years for select patients.

\section{Precautions and safety}

Clinical practice considerations

The recommendations presented here are derived from those developed for the use of infliximab in the treatment of Crohn's disease (48). The information listed below may not reflect the material presented in the product monograph.

\section{Infliximab should not be administered to the following patients:}

- Patients who have a known active infection (viral, tubercular, bacterial or atypical) (49-51). The standard tuberculin skin test (TST) is subject to anergy in the case of inflammatory bowel disease patients (52). Even if the purified protein derivative reaction is negative (given the unreliability of the testing procedure), patients should be asked to have a chest radiograph, provide a detailed travel history, report any possible tuberculosis exposures and provide details of symptoms such as a chronic cough or weight loss. In addition, an alternative to TST that should be considered is a quantitative immune assay such as QuantiFERON-TB Gold (Cellestis, Australia), which is recommended by the Centers for Disease Control and Prevention in preference over the TST (53).

- Patients with class III/IV congestive heart failure or central nervous system demyelinating syndromes $(51,54-56)$.

- Patients who have a current malignancy other than nonmelanoma skin cancer (51).

\section{Infliximab can be administered to the following patients with caution:}

- Patients with inactive or latent tuberculosis. If these conditions are suspected, appropriate consultation and 
appropriate treatment should be initiated before infliximab is started $(51,57)$.

- Patients with a previous malignancy (51).

- Women who are pregnant, lactating or unwilling to use appropriate birth control during infliximab therapy $(51,58-62)$.

- Men who are concerned about their fertility (63).

\section{Adverse events \\ Clinical practice considerations}

Because no published information on the safety of infliximab treatment of UC for more than 54 weeks was available, the information below relies on studies in which infliximab was used for 54 weeks or less and from studies on the use of infliximab to treat rheumatoid arthritis and Crohn's disease for more than 54 weeks (reviewed in [64-66]).

\section{Lymphoproliferative disorders or malignancies}

- At the present time, there is no consensus regarding the estimated lymphoma risk for patients treated with infliximab (64). Recent data from large registries (60) suggest that the lymphoma risk is no different than that in the general population. However, most experts believe that added immunosuppression does impart some small cumulative risk of malignancy. For instance, a 2005 meta-analysis by Kandiel et al (67) found that inflammatory bowel disease patients who were receiving 6-mercaptopurine or azathioprine therapy had an increased RR for developing lymphoma of 4.18 (95\% CI 2.07 to 7.51) (67). Nevertheless, the cause of the increased risk could not be specifically identified.

The authors attributed the increased risk to either the medications or the severity of the underlying disease, or a combination of these factors.

The many studies that compare the risks for patients receiving infliximab with those of the general population find standard incidence ratios of 2.6 to 11.5 . However, it is also true that a study comparing rheumatoid arthritis patients who were receiving infliximab therapy with those who were not, found no increased risk of lymphoma (68).

The 5000-patient Therapy, Resource, Evaluation and Assessment Tool (TREAT) registry for infliximab use for Crohn's disease has shown an incidence of malignancy that is the same as that for Crohn's disease patients receiving other treatments, although this information has only been collected for a period of two years (69). In addition, a meta-analysis of randomized, placebo-controlled trials found evidence that the studies' rheumatoid arthritis patients receiving infliximab were at increased risk for serious infections, as well as a dosedependent increased risk of malignancies (70).

Finally, Health Canada has issued an advisory (25) reporting the development of hepatosplenic T-cell lymphoma, a very rare malignancy, by six pediatric patients receiving infliximab treatment in the United States for Crohn's disease. An additional two cases have now been reported (27). Hepatosplenic T-cell lymphoma is a particularly aggressive cancer, and six of the eight patients have died. It remains unclear whether infliximab is a causal or synergistic agent, because the children were concomitantly taking medications (6-mercaptopurine or azathioprine) that are known mutagens (71). The response of most, but not all, pediatric gastroenterologists who take a risk-benefit approach has been to discontinue the concomitant immunosuppressive therapy if patients are to receive regularly scheduled maintenance infliximab infusions.

\section{Mortality}

- Two studies have found a mortality increase in groups of Crohn's disease patients receiving infliximab therapy (15). In a cohort of 217 patients studied over two years, there was a $1.3 \%$ to $1.8 \%$ increase above the established annual Crohn's disease mortality rate (69). At the Mayo clinic, in a group of 500 patients treated with infliximab for Crohn's disease, five deaths (1\%) were directly attributed to this therapeutic approach (72). Although the occurrence is rare, infliximab carries a potential mortality that should be carefully weighed and discussed with the patient. There is currently no infliximab mortality data for patients with UC.

- Mortality associated with infliximab was increased in more severe disease cases and when concomitant corticosteroids were used.

\section{Infections}

- As with other immunomodulatory drugs, infliximab therapy increases the risk of developing nonserious infections (RR of approximately 2); however, the data on serious infections are inconsistent (64). Examples of reported serious infections include sepsis, pneumonia, cellulitis and intra-abdominal abscess (66). Thus, infliximab should not be administered to a patient who has a clinically active infection.

- Reports of bacterial infection (eg, listeriosis and salmonellosis) in all organs of infliximab patients indicate that nonpasteurized dairy products should be avoided by those taking this drug (66).

- Patients who are at a high risk of having chronic hepatitis B infection should be screened before the initiation of infliximab therapy.

\section{Infusion reactions}

- Approximately $10 \%$ of infliximab infusions are associated with mild reactions such as headaches, dizziness, fever, chills, chest pain, cough dyspnea or pruritis. These reactions occur within $1 \mathrm{~h}$ to $2 \mathrm{~h}$ after infusion and can be alleviated by reducing the rate of infusion or by pretreatment with an $\mathrm{H}_{1}$-receptor antagonist $(38,64,66)$. In A Crohn's disease Clinical study Evaluating infliximab in a New long-term Treatment regimen (ACCENT I) study $(49,73), 83$ of 1189 (7\%) infliximab infusions resulted in a mild reaction. In the ACT 1 and ACT 2 trials, $11.4 \%$ of the patients receiving infliximab experienced infusion reactions (44 of 484), compared with $9.4 \%$ of those receiving a placebo (23 of 244) (5).

- For reasons that are unclear, one in 1000 infliximab infusions result in a serious reaction (66). 


\section{Delayed hypersensitivity-like reactions (serum sickness-like} disorders)

- Delayed reactions can occur three to 14 days after episodic infliximab infusions and include, but are not limited to, myalgia, fever, rash, pruritis, dysphagia, urticaria and headaches; these reactions are akin to a serum sickness disorder (66). Typically, these reactions disappear either spontaneously or after a short course of corticosteroid therapy. In the ACCENT I trial, approximately $2 \%$ of patients had these reactions (49). In the ACT 1 and ACT 2 trials, three patients who received either $5 \mathrm{mg} / \mathrm{kg}$ or $10 \mathrm{mg} / \mathrm{kg}$ of infliximab had delayed hypersensitivity reactions $(n=484)$, as compared with two patients in the placebo study group $(n=244)(5)$.

\section{Other}

- Cases of aplastic anemia, pancytopenia, vasculitis, hepatitis, reversible mono/poly neuropathies and demyelination have been attributed to infliximab therapy. A causal relationship with the infliximab treatment has not been established $(5,64)$.

\section{Commentary}

- Infliximab is a relatively new drug, having been introduced into clinical practice in 1998. As such, the long-term side effects of infliximab therapy are currently unknown. Careful clinical surveillance of patients receiving this therapy is necessary.

\section{UC risk-benefits associated with treatment options}

Clinical practice considerations

Surgical treatment for UC should always be seen as an option, especially if the patient is a candidate for a proctocolectomy and ileal pouch-anal anastomosis.

\section{Commentary}

- Although this type of surgery removes the target organ and the disease, and eliminates the risk of colorectal cancer, functional limitations and both short-term and long-term complications are associated with surgery. Therefore, patients should be well informed as to the functional outcomes of surgery, as well as the possibility that prolonged medical therapy may lengthen the duration of disease and also increase the risk of adverse outcomes, such as the development of dysplasia or colorectal cancer.

- Risks and benefits associated with infliximab therapy that need to be discussed by physician and patient before they come to a decision on the course of treatment include cancer risks, the likelihood of flares, screening issues and mortality risks.

- Risks and benefits associated with surgical interventions that need to be discussed by the specialist and patient include those to do with pouchitis, infertility and mortality.

- Delaying the institution of therapy in a patient with active disease, whether it is medical or surgical in nature, potentially increases patient morbidity and may promote disease severity escalation.
Potential clinical indications

Clinical practice considerations

Low-grade evidence suggests that there are benefits to infliximab therapy for UC in the following clinical situations:

- For patients presenting with symptoms of pouchitis, with and without a fistula, who are refractory to medical treatment, infliximab therapy has been successful in some cases (74-76). Pouchitis with a fistula may be misdiagnosed with Crohn's disease, and after infliximab therapy should be carefully evaluated.

- Inflammatory bowel disease of unknown diagnosis in spite of extensive testing and where the condition is refractory to conventional medical treatment may respond to infliximab therapy $(15,77)$.

- Other manifestations of UC such as sacroiliitis, peripheral arthropathy (78) and pyoderma gangrenosum may also respond to infliximab therapy (79).

ACKNOWLEDGEMENTS: The authors graciously acknowledge the efforts of Kathleen Ismond for her tireless researching and summary of the literature, and for the invaluable construction and editorial comments of the manuscript itself.

DISCLOSURE OF POTENTIAL CONFLICT OF INTEREST: Dr Levinus A Dieleman and Sunil Patel have no industry or government relationships to report

ADVISORY BOARD MEMBERS: Abbott: Drs Alain Bitton, Anne-Marie Griffiths, Charles N Bernstein, Ernest Seidman, Guy Aumais, Gordon R Greenberg, Pierre Pare, Robert Enns, Remo Panaccione, Robert Penner, Richard N Fedorak; Amgen: Dr Denis Franchimon; AstraZeneca: Drs Brian G Feagan, Robert Enns; Axcan: Edmond-Jean Bernard, Guy Aumais, John K Marshall, Richard N Fedorak; Canadian Agency for Drugs and Technology in Health: Dr John K Marshall; Celltech: Dr Brian G Feagan; Centocor: Drs Anne-Marie Griffiths, Denis Franchimont; Elan: Dr Remo Panaccione; Elan/Biogen: Drs Brian G Feagan, John K Marshall; Ferring: Drs Edmond-Jean Bernard, Guy Aumais, Remo Panaccione; Nestle Nutrition: Dr Ernest Seidman; Proctor $\mathbb{E}$ Gamble: Drs Ernest Seidman, A Hillary Steinhart, John K Marshall, Pierre Pare, Remo Panaccione; Prometheus Laboratories: Dr Ernest Seidman; Protein Design Labs, Inc: Dr Brian G Feagan; Schering: Drs Alain Bitton, Anne-Marie Griffiths, Brian G Feagan, Craig Render, Denis Franchimont, Edmond-Jean Bernard, Ernest Seidman, Guy Aumais, Gordon R Greenberg, A Hillary Steinhart, John K Marshall, Robert Enns, Richard N Fedorak, Remo Panaccione, Robert Penner; Shire: Drs Charles N Bernstein, Guy Aumais, A Hillary Steinhart, John K Marshall, Robert Enns, Remo Panaccione, Richard N Fedorak; Synta: Dr Brian G Feagan; UCB Pharma: Drs Alain Bitton, Charles N Bernstein, Edmond-Jean Bernard, Ernest Seidman, Guy Aumais, Gordon R Greenberg, A Hillary Steinhart, John K Marshall, Ken Croitoru, Pierre Pare, Robert Enns, Richard N Fedorak, Remo Panaccione; VSL3: Dr Richard N Fedorak.

RECIPIENTS OF RESEARCH GRANTS: Abbott: Drs Brian G Feagan, A Hillary Steinhart, Pierre Pare, Remo Panaccione; Altana: Dr Richard N Fedorak; AstraZeneca: Drs Brian G Feagan, Robert Enns, Richard N Fedorak; Axcan: Drs Edmond-Jean Bernard, Richard N Fedorak, Remo Panaccione; Berlex: Dr Brian G Feagan; Boehringer Ingelheim: Dr Brian G Feagan; Bristol-Myers Squibb: Drs Guy Aumais, Pierre Pare, Remo Panaccione; Centocor: Drs Brian G Feagan, John K Marshall, Pierre Pare, Remo Panaccione; Chemocentryx: Dr Pierre Pare; Elan: Dr Remo 
Panaccione; Elan/Biogen: Dr John K Marshall; Ferring: Drs Richard N Fedorak, Remo Panaccione; Jansen: Dr Remo Panaccione; Millenium: Drs Remo Panaccione, Brian G Feagan; Nestle Nutrition: Dr Ernest Seidman; Novartis: Dr Brian G Feagan; Otsuka: Drs Brian G Feagan, A Hillary Steinhart, Pierre Pare; Proctor $\&$ Gamble: Drs Edmond-Jean Bernard, A Hillary Steinhart, Pierre Pare, Remo Panaccione; Prometheus Laboratories: Dr Ernest Seidman; Protein Design Labs: Dr John K Marshall; Schering: Drs Alain Bitton, Anne-Marie Griffiths, Brian G Feagan, Denis Franchimont, Edmond-Jean Bernard, A Hillary Steinhart, Robert Enns, Richard N Fedorak, Remo Panaccione; Synta: Dr Brian G Feagan; Tillots: Drs Brian G Feagan, Guy Aumais; UCB Pharma: Dr A Hillary Steinhart; VSL: Drs Pierre Pare, Richard N Fedorak.

PARTICIPANTS IN SPEAKER'S BUREAU: Abbott: Drs Guy Aumais, John K Marshall, Pierre Pare, Richard N Fedorak, Remo Panaccione; Altana: Drs Robert Enns, Richard N Fedorak; AstraZeneca: Drs Ken Croitoru, Robert Enns, Richard N Fedorak, Remo Panaccione; Axcan: Drs Charles N Bernstein, Guy Aumais, Pierre Pare, Richard N Fedorak; Byk Solvay: Dr Remo Panaccione; Centocor: Dr Remo Panaccione; Elan: Dr Remo Panaccione; Ferring: Drs Guy Aumais, Richard N Fedorak; Jansen: Dr Remo Panaccione; Proctor \& Gamble: Drs Charles N Bernstein, Edmond-Jean Bernard, A Hillary Steinhart, John K Marshall, Ken Croitoru; Prometheus Laboratories: Drs Ernest Seidman, Remo Panaccione; Schering: Drs Alain Bitton, Anne-Marie Griffiths, Edmond-Jean Bernard,

\section{REFERENCES}

1. Armuzzi A, De Pascalis B, Lupascu A, et al. Infliximab in the treatment of steroid-dependent ulcerative colitis. Eur Rev Med Pharmacol Sci 2004;8:231-3.

2. Jarnerot G, Hertervig E, Friis-Liby I, et al. Infliximab as rescue therapy in severe to moderately severe ulcerative colitis: A randomized, placebo-controlled study. Gastroenterology 2005;128:1805-11.

3. Ochsenkuhn T, Sackmann M, Goke B. Infliximab for acute, not steroid-refractory ulcerative colitis: A randomized pilot study. Eur J Gastroenterol Hepatol 2004;16:1167-71.

4. Probert CS, Hearing SD, Schreiber S, et al. Infliximab in moderately severe glucocorticoid resistant ulcerative colitis: A randomised controlled trial. Gut 2003;52:998-1002.

5. Rutgeerts P, Sandborn WJ, Feagan BG, et al. Infliximab for induction and maintenance therapy for ulcerative colitis. N Engl J Med 2005;353:2462-76.

6. Sands BE, Tremaine WJ, Sandborn WJ, et al. Infliximab in the treatment of severe, steroid-refractory ulcerative colitis: A pilot study. Inflamm Bowel Dis 2001;7:83-8.

7. Truelove SC, Witts LJ. Cortisone in ulcerative colitis; preliminary report on a therapeutic trial. Br Med J 1954;2:375-8.

8. Lawson MM, Thomas AG, Akobeng AK. Tumour necrosis factor alpha blocking agents for induction of remission in ulcerative colitis. Cochrane Database Syst Rev 2006:CD005112.

9. Maser EA, Villela R, Silverberg MS, Greenberg GR. Association of trough serum infliximab to clinical outcome after scheduled maintenance treatment for Crohn's disease. Clin Gastroenterol Hepatol 2006;4:1248-54

10. Vermeire S, Norman M, Van Assche G, Baert F, D'Haens G, Rutgeerts P. Effectiveness of concomitant immunosuppressive therapy to suppress the formation of antibodies to infliximab in Crohn's disease. Gut 2007;56:1226-31.

11. Anderson PJ. Tumor necrosis factor inhibitors: Clinical implications of their different immunogenicity profiles. Semin Arthritis Rheum 2005;34(5 Suppl 1):19-22.

12. Kozuch PL, Hanauer SB. General principles and pharmacology of biologics in inflammatory bowel disease. Gastroenterol Clin North Am 2006;35:757-73.

13. Friesen CA, Calabro C, Christenson K, et al. Safety of infliximab treatment in pediatric patients with inflammatory bowel disease. J Pediatr Gastroenterol Nutr 2004;39:265-9.
Guy Aumais, Gordon R Greenberg, A Hillary Steinhart, John K Marshall, Ken Croitoru, Pierre Pare, Robert Enns, Richard N Fedorak, Remo Panaccione; Shire: Dr Guy Aumais; UCB Pharma: Dr Richard N Fedorak.

SIGNIFICANT SHAREHOLDINGS (more than \$50,000): Santarus: Dr Brian G Feagan.

RECEIPT OF CONSULTATION FEES (INCLUDING SPEAKER'S HONORARIA LISTED BY DR ROBERT PENNER): Abbott: Drs Brian G Feagan, Remo Panaccione, Robert Penner, Richard N Fedorak; AstraZeneca: Drs Remo Panaccione, Robert Penner; Axcan: Dr Robert Penner; Bristol Meyers Squibb: Drs Brian G Feagan, Remo Panaccione; Celgene: Dr Brian G Feagan; Celltech: Dr Brian G Feagan; Centocor: Drs Brian G Feagan, Remo Panaccione; Combinatorx: Dr Brian G Feagan; Elan: Drs Brian G Feagan, Robert Penner; Ferring: Drs Remo Panaccione, Robert Penner; Glaxo-Smith Kline: Dr Remo Panaccione; ISIS: Dr Brian G Feagan; Janssen-Orth: Dr Brian G Feagan; Millenium: Dr Brian G Feagan; Napo: Dr Brian G Feagan; Osiris: Drs Brian G Feagan, Richard N Fedorak; Proctor $\mathcal{E}$ Gamble: Drs Brian G Feagan, Remo Panaccione; Protein Design Labs: Dr Brian G Feagan; Santarus: Dr Brian G Feagan; Schering: Drs Brian G Feagan, Remo Panaccione, Robert Penner, Richard N Fedorak; Serono: Dr Brian G Feagan; Shire: Drs Remo Panaccione, Richard N Fedorak; Synta: Dr Brian G Feagan; Teva: Dr Brian G Feagan; UCB Pharma: Drs Brian G Feagan, Remo Panaccione, Richard N Fedorak.
14. Jacobstein DA, Markowitz JE, Kirschner BS, et al. Premedication and infusion reactions with infliximab: Results from a pediatric inflammatory bowel disease consortium. Inflamm Bowel Dis 2005;11:442-6

15. Ljung T, Karlen P, Schmidt D, et al. Infliximab in inflammatory bowel disease: Clinical outcome in a population based cohort from Stockholm County. Gut 2004:53:849-53.

16. Mamula P, Markowitz JE, Brown KA, Hurd LB, Piccoli DA, Baldassano RN. Infliximab as a novel therapy for pediatric ulcerative colitis. J Pediatr Gastroenterol Nutr 2002;34:307-11.

17. Ardizzone S, Maconi G, Russo A, Imbesi V, Colombo E, Bianchi PG. Randomised controlled trial of azathioprine and 5-aminosalicylic acid for treatment of steroid dependent ulcerative colitis. Gut 2006;55:47-53.

18. Hawthorne AB, Logan RF, Hawkey CJ, et al. Randomised controlled trial of azathioprine withdrawal in ulcerative colitis. BMJ 1992;305:20-2.

19. Kozarek RA. Review article: Immunosuppressive therapy for inflammatory bowel disease. Aliment Pharmacol Ther 1993; 7:117-23.

20. Oren R, Arber N, Odes S, et al. Methotrexate in chronic active ulcerative colitis: A double-blind, randomized, Israeli multicenter trial. Gastroenterology 1996;110:1416-21.

21. Mate-Jimenez J, Hermida C, Cantero-Perona J, Moreno-Otero R. 6-mercaptopurine or methotrexate added to prednisone induces and maintains remission in steroid-dependent inflammatory bowel disease. Eur J Gastroenterol Hepatol 2000;12:1227-33.

22. Maini R, St Clair EW, Breedveld F, et al. Infliximab (chimeric anti-tumour necrosis factor alpha monoclonal antibody) versus placebo in rheumatoid arthritis patients receiving concomitant methotrexate: A randomised phase III trial. ATTRACT Study Group. Lancet 1999;354:1932-9.

23. Maini RN, Breedveld FC, Kalden JR, et al. Therapeutic efficacy of multiple intravenous infusions of anti-tumor necrosis factor alpha monoclonal antibody combined with low-dose weekly methotrexate in rheumatoid arthritis. Arthritis Rheum 1998;41:1552-63.

24. Mamula P, Markowitz JE, Cohen LJ, von AD, Baldassano RN. Infliximab in pediatric ulcerative colitis: Two-year follow-up. J Pediatr Gastroenterol Nutr 2004:38:298-301.

25. Health Canada. Possible Association of REMICADE with hepatosplenic T-cell lymphoma in pediatric and young adult patients with Crohn's disease. <http://www.hc-sc.gc.ca/dhp- 
mps/medeff/advisories-avis/prof/2006/remicade_3 hpc-cps_e.html> (Version current at February 8, 2008).

26. Thayu M, Markowitz JE, Mamula P, Russo PA, Muinos WI, Baldassano RN. Hepatosplenic T-cell lymphoma in an adolescent patient after immunomodulator and biologic therapy for Crohn disease. J Pediatr Gastroenterol Nutr 2005;40:220-2.

27. Mackey AC, Green L, Liang LC, Dinndorf P, Avigan M. Hepatosplenic $\mathrm{T}$ cell lymphoma associated with infliximab use in young patients treated for inflammatory bowel disease. J Pediatr Gastroenterol Nutr 2007;44:265-7.

28. Lam EC, Bailey RJ. Infliximab salvage therapy after cyclosporine in an acute flare of chronic ulcerative colitis. Can J Gastroenterol 2003;17:198-200.

29. Mahe E, Descamps V, Grossin M, Fraitag S, Crickx B. CD30+ T-cell lymphoma in a patient with psoriasis treated with ciclosporin and infliximab. Br J Dermatol 2003;149:170-3.

30. Eidelwein AP, Cuffari C, Abadom V, Oliva-Hemker M. Infliximab efficacy in pediatric ulcerative colitis. Inflamm Bowel Dis 2005;11:213-8.

31. Gornet JM, Couve S, Hassani Z, et al. Infliximab for refractory ulcerative colitis or indeterminate colitis: An open-label multicentre study. Aliment Pharmacol Ther 2003;18:175-81.

32. Kohn A, Prantera C, Pera A, Cosintino R, Sostegni R, Daperno M. Anti-tumour necrosis factor alpha (infliximab) in the treatment of severe ulcerative colitis: Result of an open study on 13 patients. Dig Liver Dis 2002;34:626-30.

33. Kohn A, Prantera C, Pera A, Cosintino R, Sostegni R, Daperno M Infliximab in the treatment of severe ulcerative colitis: A follow-up study. Eur Rev Med Pharmacol Sci 2004;8:235-7.

34. Lee K, Binion DG, Kugathasan S. Immediate and long-term safety of infliximab in children with IBD. Gastroenterology 2005;128:A580-1. (Abst)

35. Russell GH, Katz AJ. Infliximab is effective in acute but not chronic childhood ulcerative colitis. J Pediatr Gastroenterol Nutr 2004;39:166-70.

36. Kooros K, Katz AJ. Infliximab therapy in pediatric Crohn's pouchitis. Inflamm Bowel Dis 2004;10:417-20.

37. Leung Y, Panaccione R, Jones J. Systematic review looking at the effectiveness of azathioprine or 6-mercaptopurine for the maintenance of clinical remission in ulcerative colitis. Can J Gastroenterol 2007;21(Suppl A):133A. (Abst)

38. Baert F, Norman M, Vermeire $S$, et al. Influence of immunogenecity on the long-term efficacy of infliximab in Crohn's disease. N Engl J Med 2003;348:601-8.

39. Actis GC, Bruno M, Pinna-Pintor M, Rossini FP, Rizzetto M. Infliximab for treatment of steroid-refractory ulcerative colitis. Dig Liver Dis 2002;34:631-4.

40. Chey WY, Hussain A, Ryan C, Potter GD, Shah A. Infliximab for refractory ulcerative colitis. Am J Gastroenterol 2001;96:2373-81

41. Lees CW, Shand AG, Penman ID, Satsangi J, Arnott ID. Role of infliximab in ulcerative colitis: Further questions. Inflamm Bowel Dis 2006;12:335-7.

42. Lowry PW, Franklin CL, Weaver AL, et al. Leucopenia resulting from a drug interaction between azathioprine or 6-mercaptopurine and mesalamine, sulphasalazine, or balsalazide. Gut 2001;49:656-64

43. Chey WY. Infliximab for patients with refractory ulcerative colitis. Inflamm Bowel Dis 2001;7(Suppl 1):S30-3

44. D'Haens G. Infliximab for ulcerative colitis: Finally some answers. Gastroenterology 2005;128:2161-4.

45. Seiderer J, Goke B, Ochsenkuhn T. Safety aspects of infliximab in inflammatory bowel disease patients. A retrospective cohort study in 100 patients of a German University Hospital. Digestion 2004:70:3-9.

46. Su C, Salzberg BA, Lewis JD, et al. Efficacy of anti-tumor necrosis factor therapy in patients with ulcerative colitis. Am J Gastroenterol 2002;97:2577-84.

47. Menter A, Feldman SR, Weinstein GD, et al. A randomized comparison of continuous vs intermittent infliximab maintenance regimens over 1 year in the treatment of moderate-to-severe plaque psoriasis. J Am Acad Dermatol 2007;56:31-15.

48. Panaccione R, Fedorak RN, Aumais G, et al, for the Canadian Association of Gastroenterology. Canadian Association of Gastroenterology Clinical Practice Guidelines: The use of infliximab in Crohn's disease. Can J Gastroenterol 2004;18:503-8
49. Hanauer SB, Feagan BG, Lichtenstein GR, et al. Maintenance infliximab for Crohn's disease: The ACCENT I randomised trial. Lancet 2002;359:1541-9.

50. Sands BE, Anderson FH, Bernstein CN, et al. Infliximab maintenance therapy for fistulizing Crohn's disease. N Engl J Med 2004:350:876-85

51. Massironi S, Losco A, Basilisco G. Drug side-effects in IBD. Aliment Pharmacol Ther 2002;16:1831

52. Mow WS, Abreu-Martin MT, Papadakis KA, et al. High incidence of anergy in inflammatory bowel disease patients limits the usefulness of PPD screening before infliximab therapy. Clin Gastroenterol Hepatol 2004;2:309-13.

53. Mazurek GH, Jereb J, Lobue P, Iademarco MF, Metchock B, Vernon A, for the Division of Tuberculosis Elimination, National Center for HIV, STD, and TB Prevention, Centers for Disease Control and Prevention (CDC). Guidelines for using QuantiFERON-TB Gold test for detecting Mycobacterium tuberculosis infection, United States. MMWR Recomm Rep 2005;54:49-55. (Erratum in MMWR Morb Mortal Wkly Rep 2005; 54:1288)

54. von Haehling S, Jankowska EA, Anker SD. Tumour necrosis factor-alpha and the failing heart - pathophysiology and therapeutic implications. Basic Res Cardiol 2004;99:18-28.

55. Chung ES, Packer M, Lo KH, Fasanmade AA, Willerson JT, for the Anti-TNF Therapy Against Congestive Heart Failure Investigators. Randomized, double-blind, placebo-controlled, pilot trial of infliximab, a chimeric monoclonal antibody to tumor necrosis factor-alpha, in patients with moderate-to-severe heart failure: Results of the anti-TNF Therapy Against Congestive Heart Failure (ATTACH) trial. Circulation 2003;107:3133-40.

56. Kwon HJ, Cote TR, Cuffe MS, Kramer JM, Braun MM. Case reports of heart failure after therapy with a tumor necrosis factor antagonist. Ann Intern Med 2003;138:807-11

57. Wallis RS, Broder MS, Wong JY, Hanson ME, Beenhouwer DO. Granulomatous infectious diseases associated with tumor necrosis factor antagonists. Clin Infect Dis 2004:38:1261-5.

58. Sathyanarayana G, Saraya A. Ulcerative colitis and pregnancy. Trop Gastroenterol 2004;25:4-8

59. Vasiliauskas E, Dubinsky M, Barry M, Targan S. High serum levels of infliximab detected in the newborn of a mother receiving infliximab during pregnancy. Gastroenterology 2005;128:A26. (Abst)

60. Beaulieu DB, Otterson MF, Newcomer J, et al. IBD pregnancy complications and outcomes in the era of immunomodulator and biologic therapy: a tertiary referral center experience. Gastroenterology 2005;128(Suppl 2):316. (Abst)

61. Aberra FN. To be or not to be: Infliximab during pregnancy? Inflamm Bowel Dis 2006;12:76-8.

62. Katz JA, Antoni C, Keenan GF, Smith DE, Jacobs SJ, Lichtenstein GR. Outcome of pregnancy in women receiving infliximab for the treatment of Crohn's disease and rheumatoid arthritis. Am J Gastroenterol 2004;99:2385-92.

63. Mahadevan U, Terdiman JP, Aron J, Jacobson S, Turek P. Infliximab and semen quality in men with inflammatory bowel disease. Inflamm Bowel Dis 2005;11:395-9.

64. Desai SB, Furst DE. Problems encountered during anti-tumour necrosis factor therapy. Best Pract Res Clin Rheumatol 2006;20:757-90.

65. Lichtenstein GR, Feagan BG, Cohen RD, et al. Serious infections and mortality in association with therapies for Crohn's disease: TREAT registry. Clin Gastroenterol Hepatol 2006;4:621-30. (Erratum in 2006;4:621-30).

66. Lichtenstein GR, Abreu MT, Cohen R, Tremaine W, for the American Gastroenterological Association. American Gastroenterological Association Institute technical review on corticosteroids, immunomodulators, and infliximab in inflammatory bowel disease. Gastroenterology 2006;130:940-87

67. Kandiel A, Fraser AG, Korelitz BI, Brensinger C, Lewis JD. Increased risk of lymphoma among inflammatory bowel disease patients treated with azathioprine and 6-mercaptopurine. Gut 2005;54:1121-5.

68. Askling J, Fored CM, Baecklund E, et al. Haematopoietic malignancies in rheumatoid arthritis: Lymphoma risk and characteristics after exposure to tumour necrosis factor antagonists. Ann Rheum Dis 2005;64:1414-20. 
69. Lichtenstein GR, Cohen R, Feagan B, et al. Safety of infliximab and other Crohn's disease therapies - updated TREAT Registry data with over 10,000 patient-years of follow-up. Gastroenterology 2005;128:A580. (Abst)

70. Bongartz T, Sutton AJ, Sweeting MJ, Buchan I, Matteson EL, Montori V. Anti-TNF antibody therapy in rheumatoid arthritis and the risk of serious infections and malignancies: Systematic review and meta-analysis of rare harmful effects in randomized controlled trials. JAMA 2006;295:2275-85. (Erratum in 2006;295:2482).

71. Karran P. Thiopurines, DNA damage, DNA repair and therapyrelated cancer. Br Med Bull 2006;79-80:153-70.

72. Colombel JF, Loftus EV Jr, Tremaine WJ, et al. The safety profile of infliximab in patients with Crohn's disease: The Mayo clinic experience in 500 patients. Gastroenterology 2004;126:19-31.

73. Rutgeerts P, Feagan BG, Lichtenstein GR, et al. Comparison of scheduled and episodic treatment strategies of infliximab in Crohn's disease. Gastroenterology 2004;126:402-13.

74. Viscido A, Habib FI, Kohn A, et al. Infliximab in refractory pouchitis complicated by fistulae following ileo-anal pouch for ulcerative colitis. Aliment Pharmacol Ther 2003;17:1263-71.

75. Ferrante M, Vermeire S, Norman M, et al. Short-term response to infliximab in ulcerative colitis and pouchitis: results from a single-center experience. Gastroenterology 2006;130(Suppl 2):A658. (Abst)

76. Gionchetti P, Morselli C, Rizzello F, et al. Infliximab in the treatment of refractory pouchitis. Gastroenterology 2005;128:A578. (Abst)
77. Papadakis KA, Treyzon L, Abreu MT, Fleshner PR, Targan SR, Vasiliauskas EA. Infliximab in the treatment of medically refractory indeterminate colitis. Aliment Pharmacol Ther 2003;18:741-7.

78. Lupascu A, Armuzzi A, De PB, et al. Sacroileitis and peripheral arthropathy associated with ulcerative colitis: Effect of infliximab on both articular and intestinal symptoms. Dig Liver Dis 2004;36:423-5

79. Brooklyn TN, Dunnill MG, Shetty A, et al. Infliximab for the treatment of pyoderma gangrenosum: A randomised, double blind, placebo controlled trial. Gut 2006;55:505-9.

80. Kornbluth A, Sachar DB. Ulcerative colitis practice guidelines in adults (update): American College of Gastroenterology, Practice Parameters Committee. Am J Gastroenterol 2004;99:1371-85.

81. Truelove SC, Witts LJ. Cortisone in ulcerative colitis; final report on a therapeutic trial. Br Med J 1955;2:1041-8.

82. Schroeder KW, Tremaine WJ, Ilstrup DM. Coated oral 5-aminosalicylic acid therapy for mildly to moderately active ulcerative colitis. A randomized study. N Engl J Med 1987;317:1625-9.

83. Fagan EA, Dyck RF, Maton PN, et al. Serum levels of C-reactive protein in Crohn's disease and ulcerative colitis. Eur J Clin Invest 1982;12:351-9.

84. Travis SP, Farrant JM, Ricketts C, et al. Predicting outcome in severe ulcerative colitis. Gut 1996;38:905-10

85. Sandborn WJ. Severe ulcerative colitis. Curr Treat Options Gastroenterol 1999;2:113-8

86. Truelove SC, Jewell DP. Intensive intravenous regimen for severe attacks of ulcerative colitis. Lancet 1974;1:1067-70. 


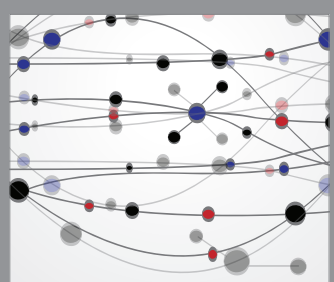

The Scientific World Journal
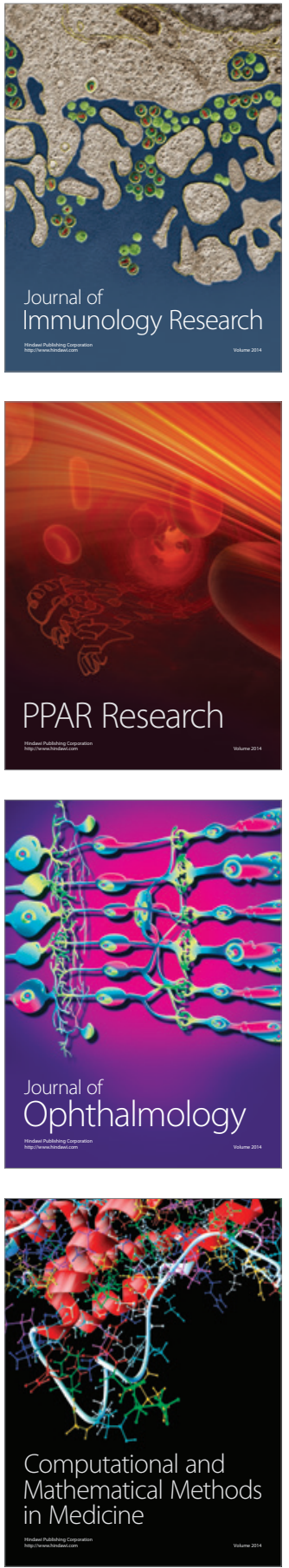

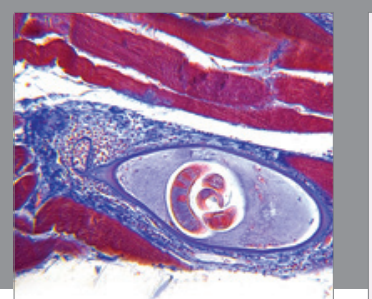

Gastroenterology Research and Practice

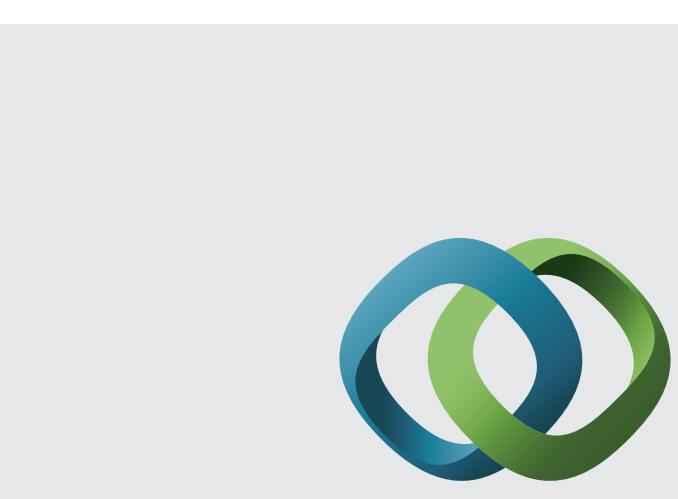

\section{Hindawi}

Submit your manuscripts at

http://www.hindawi.com
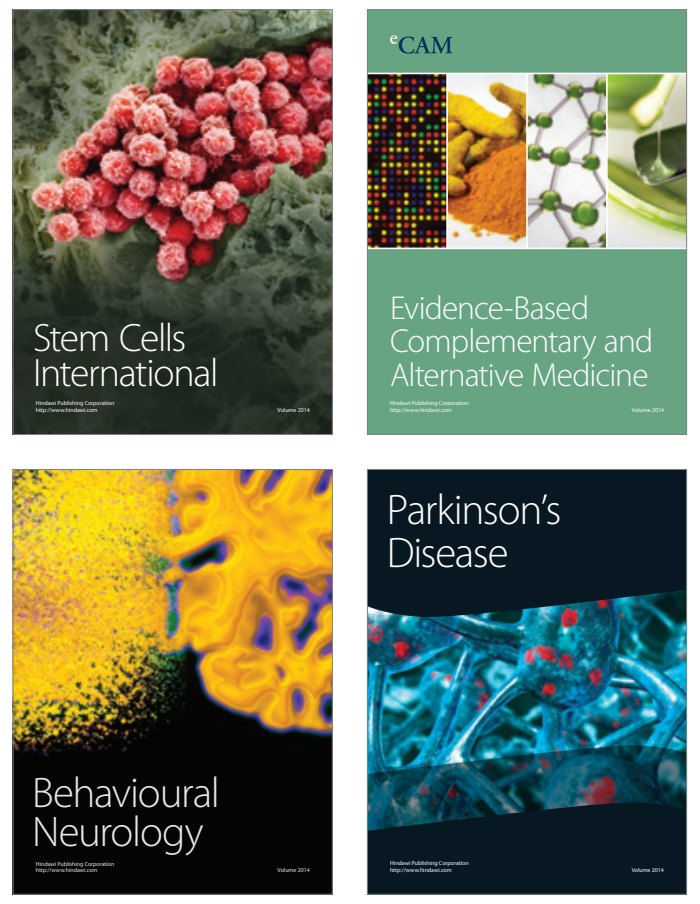
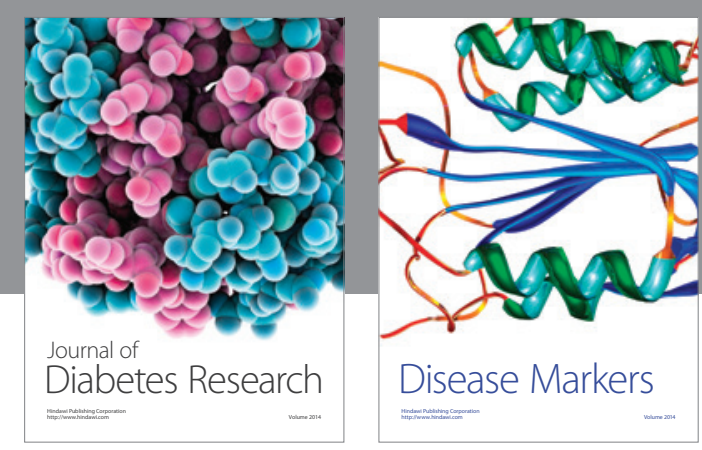

Disease Markers
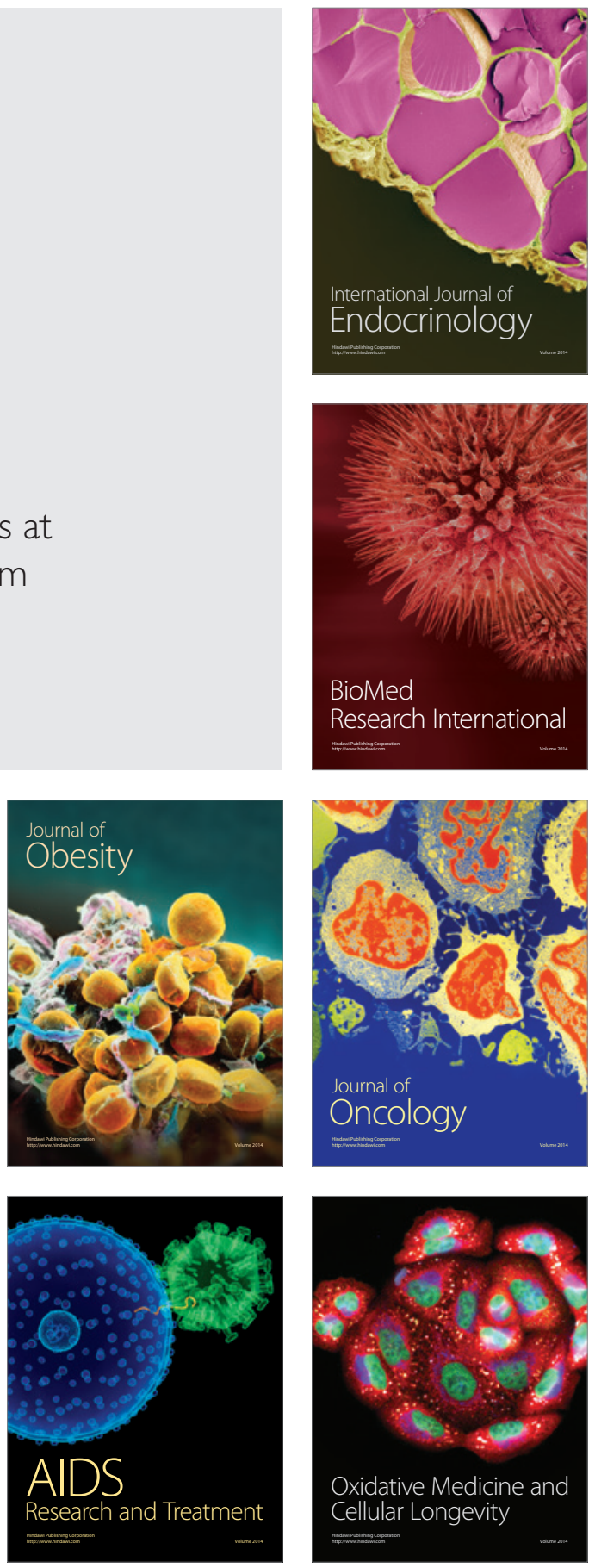